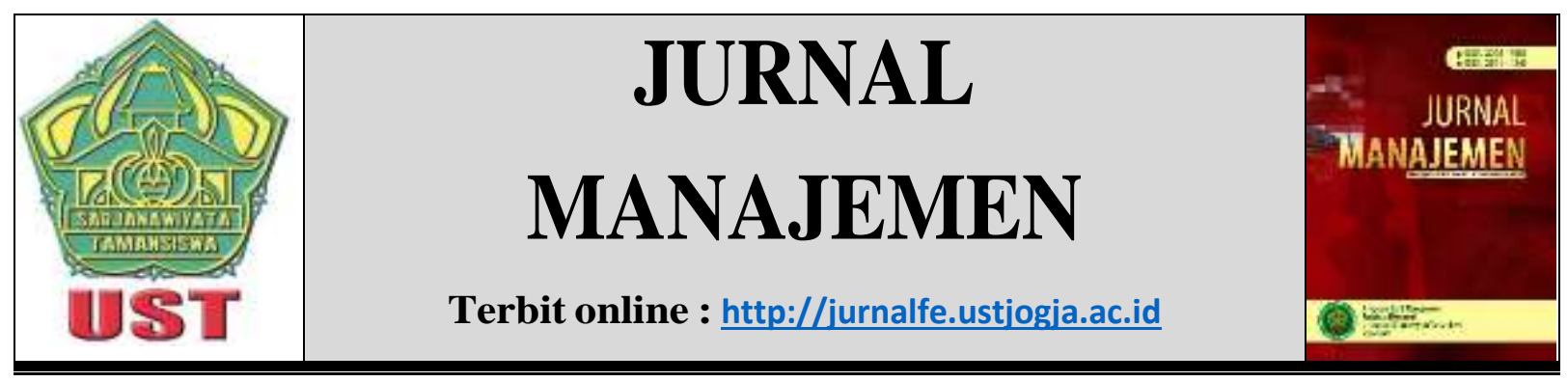

\title{
PENGARUH LINGKUNGAN KERJA FISIK DAN NON FISIK SERTA STRES KERJA TERHADAP KINERJA KARYAWAN PABRIK SUKA RASA BAKERY
}

\author{
Nanda Aulia Pangestuti
}

Fakultas Ekonomi Universitas Sarjanawiyata Tamansiswa

Email: auliapn528@gmail.com

\begin{tabular}{|c|c|}
\hline Informasi Naskah & Abstrak \\
\hline $\begin{array}{l}\text { Diterima: } 2 \text { September } \\
2020 \\
\text { Revisi: } 25 \text { November } \\
2020 \\
\text { Terbit: } 26 \text { Desember } \\
\text { 2020 } \\
\text { Kata Kunci: physical } \\
\text { work environment; } \\
\text { nonphysical; stress; } \\
\text { performance. }\end{array}$ & $\begin{array}{l}\text { This research to analize the influence of physical work } \\
\text { environment, non physical and stress on performance on employee } \\
\text { performance. This research is explanatory research with quantitative } \\
\text { approach methods. The object of this research is the permanent Pabrik } \\
\text { Suka Rasa Bakery with } 31 \text { people. The method of data collection in this } \\
\text { research used a questionnaire with a likert measurement scale while for } \\
\text { the data analysis technique in this research using multiple regression } \\
\text { analysis. Based on the hypothesis testing, the ftest is known that jointly } \\
\text { (simultaneously) physical environment, nonphysical and stress } \\
\text { significant effect on employee performance. }\end{array}$ \\
\hline
\end{tabular}

\section{PENDAHULUAN}

Organisasi dapat berjalan dengan baik dan mampu menghadapi tantangan karena didasari oleh beberapa instrumen untuk mencapai tujuannya. Instrumen untuk mencapai tujuan organisasi yang dimaksut yaitu berupa sumber daya alam berupa bahan baku, peralatan atau teknologi, modal usaha, serta sumber daya manusia berupa tenaga kerja. Setiap organisasi pastinya memiliki target untuk meningkatkan kinerja karyawannya dari waktu ke waktu. Kinerja yang baik yaitu kinerja yang kualitas dan kuantitas yang dihasilkan oleh karyawan sesuai dengan standar kerja yang telah ditetapkan oleh perusahaan (Hamid at all., 2017:173). Oleh karena itu, untuk mencapai kinerja yang lebih baik lagi dibutuhkan pula dukungan lingkungan kerja yang kondusif.

Lingkungan kerja merupakan suatu piranti yang digunakan untuk mengukur berbagai hal yang dapat memperngaruhi kinerja pegawai yang berada pada lingkungan kerja tersebut (Aji dan Budianto, 2015:100). Secara garis besar lingkungan sendiri mampu dibagi menjadi dua, yaitu lingkungan kerja fisik dan lingkungan kerja non fisik. Lingkungan kerja yang nyaman sangat berpengaruh terhadap kinerja karyawan karena karyawan enggan bekerja jika tidak ada kekompakan kerja atau ruang kerja yang tidak menyenangkan untuk para karyawan.

Karyawan dalam menyelesaikan pekerjaan mengalami tekanan atau sedang berada pada kondisi fisik atau psikis yang tidak baik maka hal itu akan berpengaruh pula terhadap kinerja karyawan itu sendiri, bahkan stres kerja juga bisa dipengaruhi oleh lingkungan kerja itu sendiri. Stres kerja sendiri mampu mempengaruhi kinerja karyawan, untuk seberapa besar pengaruh yang berdampak pada kinerja karyawan tergantung pada tingkatan stres yang dialami. 
Menghadapi semakin ketatnya usaha di bidang kuliner (beraneka ragam jenis kue) pabrik yang sudah mulai beroprasi sejak tahun 1981 ini yaitu Pabrik Suka Rasa Bakery yang beralamatkan di Munggi Pasar, Semanu, Semanu, Gunungkidul ini diharuskan mampu beradaptasi dengan keadaan pasar saat ini dan mampu bersaing serta dapat memanfaatkan peluang pasar yang ada sehingga mampu menjawab semua tantangan yang ada di pasar serta tantangan di masa yang akan mendatang. Pabrik Suka Rasa Bakery memproduksi berbagai macam kue seperti onde-onde, cake, bolu kukus, bolu gulung, wingko babat, untir-untir, kue pisang dan masih banyak lagi. Jumlah dari karyawan di pabrik ini terdiri dari 31 orang karyawan tetap. Untuk perekrutan karyawan sendiri, pemilik pabrik memilih untuk memberdayakan masyarakat sekitar terutama ibu-ibu rumah tangga, karena hampir $70 \%$ karyarawan berasal dari kaum ibu tumah tangga yang berada di sekitar pabrik. Untuk pemasaran produk ini sendiri sudah mencangkup hampir di seluruh wilayah Gunungkidul dan ada beberapa yang sudah di pasarkan di luar kota. Dengan semakin meluasnya pasar maka sangat penting untuk menjaga dan meningkatkan perfoma perusahaan dan karyawan agar mampu bertahan dipersaingan pasar yang semakin ketat. Maka untuk itu perusahaan perlu meningkatkan kinerja para karyawanya yaitu salah satunya dengan memperhatikan lingkungan kerja, karena disinilah karyawan menyelesaikan pekerjaanya, jika para karyawan merasa tidak nyaman atau terganggu dengan hal-hal yang membuat mereka tidak nyaman sehingga akan berpengaruh buruk terhadap kinerjanya. Dengan melihat fenomena lingkungan kerja yang tersedia di Suka Rasa Bakery maka dapat dikatakan adalah mulai dari suasana dalam pabrik yang terbilang panas, hawa dalam pabrik yang lumayan pengap karena kurangnya fentilasi (sudah terdapat fentilasi namun bisa dibilang sangat kurang) dan disamping fasilitas yang kurang memadai para karyawan juga harus menyelsaikan pekerjaan dengan taget yang sudah ditentukan.

\section{KAJIAN PUSTAKA DAN HIPOTESIS Lingkungan Kerja Fisik}

Lingkungan kerja fisik merupakan suatu keadaan lingkungan kerja dalam bentuk material atau fisik dan berpengaruh terhadap kinerja karyawan (Joseph, 2016:410). Organisasi mampu menetukan tindakan yang dapat dilakukan dengan penyesuaian kondisi karakteristik dari para karyawan yang kemudian mampu dijadikan sebagai dasar untuk memikirkan lingkungan fisik yang sesuai. Ada beberapa hal yang mampu mempengaruhi lingkungan kerja fisik yaitu meliputi pewarnaan, kebersihan, pertukaran udara, penerangan, keamanan dan kebisingan (Nitisemito dalam Virgiyanti dan Sunuharyo, 2018:57).

\section{Lingkungan Kerja Non Fisik}

Lingkungan kerja non fisik merupakan suatu keadaan yang berkaitan dengan hubungan kerja, baik itu hubungan antar karyawan maupun hubungan karyawan dengan atasan (Aslami dan Absah, 2018:477). Linkungan kerja non fisik didasari oleh beberapa indikator yang mampu mempengaruhi peforma karyawan dalam menjalankan tugas dan kewajibannya di perusahaan mulai dari miskomunikasi, penyalagunaan fasilitas, tidak fokus kerja, terdapat tekanan, etika berpakaian dan tingkah laku (Joseph, 2016:412).

\section{Stres Kerja}

Stres kerja merupakan bahaya fisik dan respon dari emosi yang muncul ketika seseorang tidak terpenuhi keinginannya, kemampuan, sumber daya dan kebutuhannya (Ahmad et al. 2018:18). Stres yang terlalu lama akan memunculkan rasa ingin keluar dari pekerjaan yang berasal dari dalam diri karyawan, dampak buruk inilah yang menjadi kerugian dari timbulnya stres yang dialami karyawan. Dalam meingkatkan kinerja karyawan, perusahaan perlu melihat indikator-indikator berikut ini yang bisa dijadikan sebagai acuan meliputi intimidasi, kemampuan, ketidak cocokan dengan pekerjaan, pekerjaan yang beresiko, beban berlebih, dan faktor individu (Igor S dalam Iqbal, 2016:31). 


\section{Kinerja Karyawan}

Kinerja karyawan merupakan hasil kerja yang dicapai karyawan dalam melaksanakan tanggung jawab dan tugas kerjanya sehingga mampu memberikan kontribusinya terhadap organisasi (Rosita dan Cahyani, 2019:134). Kinerja yang baik merupakan kinerja yang memiliki kualitas dan kuantitas yang dimiliki oleh karyawan dengan standar kerja yang sebelumnya telah ditetapkan oleh organisasi. Untuk menilai kinerja seorang karyawan, dapat dilihat dari indikator-indikator berikut ini meliputi kualitas kinerja, ketepatan waktu, kerjasama antar karyawan, tanggung jawab, komunikasi, kemampuan dan inisiatif (Sugiono dalam Aji dan Budianto 2015, 110).

\section{PENGEMBANGAN HIPOTESIS}

Lingkungan kerja fisik memiliki pengaruh yang positif dan signifikan terhadap kinerja karyawan, hipotesis ini sejalan dengan penelitian yang telah dilakukan oleh Eka dkk. 2016 dapat diketahui bahwa variabel lingkungan kerja fisik memiliki pengaruh yang positif dan signifikan terhadap variabel kinerja.

H1: Terdapat pengaruh yang positif dan signifikan dari lingkungan kerja fisik (X1) terhadap kinerja karyawan (Y) pada Pabrik Suka Rasa Bakery.

Lingkungan kerja non fisik berpengaruh positif dan signifikan terhadap kinerja karyawan, hipotesis ini sejalan dengan hasil penelitian yang dilakukan oleh Noorainy (2017) menyatakan bahwa lingkungan kerja non fisik berpengaruh positif dan signifikan terhadap kinerja karyawan.

H2 : Terdapat pengaruh yang positif dari lingkungan kerja non fisik (X2) terhadap kinerja karyawan (Y) pada Pabrik Suka Rasa Bakery.

Stres kerja berpengaruh positif dan signifikan terhadap kinerja karyawan, hipotesis ini sejalan dengan hasil penelitian yang telah dilakukan oleh Oemar dan Leo (2017) menyatakan bahwa stres kerja yang dialami karyawan bersifat kuat dan positif.

H3: Terdapat pengaruh stres kerja (X2) terhadap kinerja karyawan (Y) secara signifikan pada Pabrik Suka Rasa Bakery.

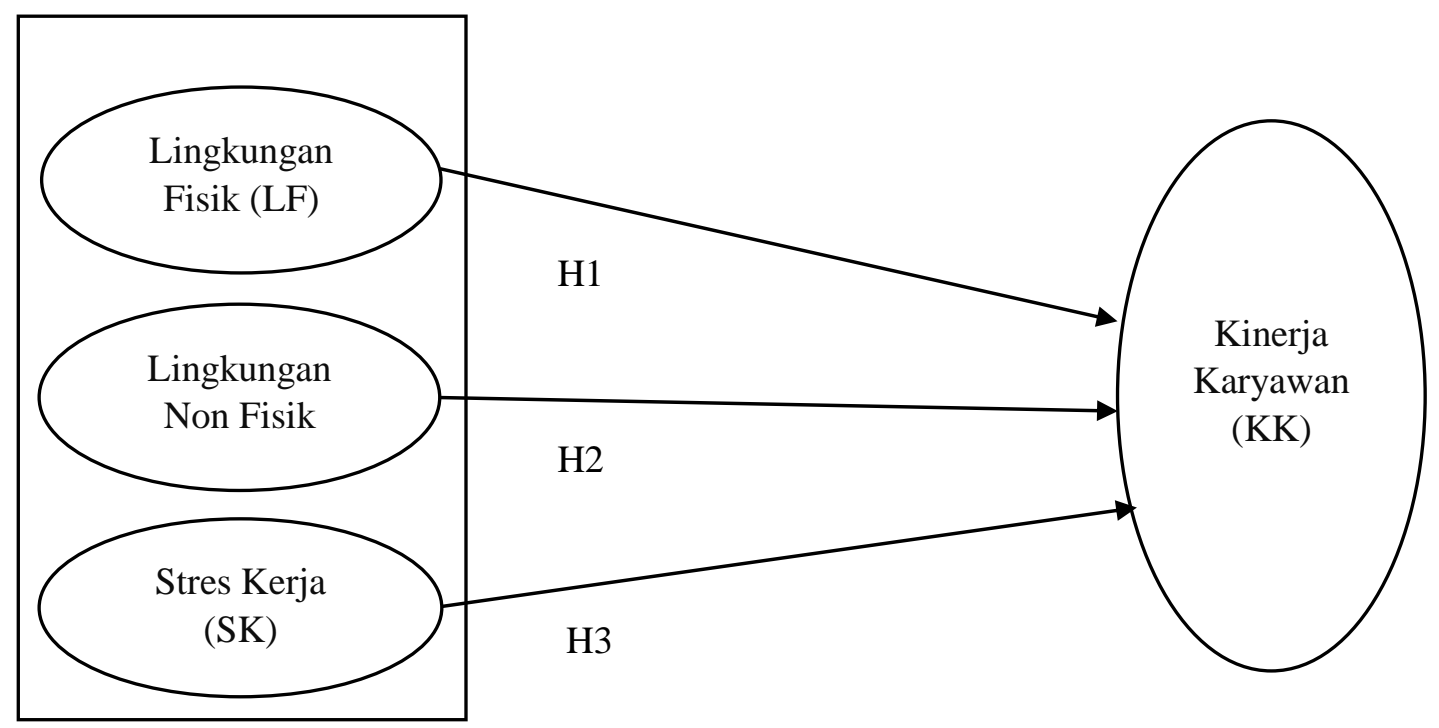

Gambar 1. Kerangka Pikir Penelitian

\section{METODE PENELITIAN}

Penelitian ini bersifat explanatory research dengan metode pendekatan kuantitatif. Objek dalam penelitian ini adalah karyawan tetap Pabrik Suka Rasa Bakery yaitu 31 orang. Dalam penelitian ini metode pengumpulan data menggunakan kuesioner dengan skala perhitungan likerd 
sedangkan untuk teknik analisis data dalam penelitian ini menggunakan analisis regresi berganda dengan persamaan regresi sebagai $Y=1.266+-0,230 X_{1}+0,640 X_{2}+0,309 X_{3}+$ e.

\section{HASIL DAN PEMBAHASAN}

Tabel 1 Jenis Kelamin, Usia \& Masa Kerja

\begin{tabular}{ccccccccc}
\hline Jenis Kelamin & F & $\%$ & Usia & F & $\%$ & Masa Kerja & F & $\%$ \\
& & & & & & & & \\
\hline Laki-laki & 9 & 29,0 & $<20$ & 1 & 3,2 & $<2$ & 10 & 32,3 \\
Perempuan & 22 & 71,0 & $21-30$ & 18 & 58,1 & $2-5$ & 15 & 48,4 \\
& & & $31-40$ & 8 & 25,8 & $5-10$ & 6 & 19,4 \\
& & & $>40$ & 4 & 12,9 & & & \\
\hline
\end{tabular}

Berdasarkan Tabel 1 dapat disimpulkan bahwa karyawan Pabrik Suka Rasa Bakery didominasi oleh perempuan dengan presentase mencapai 71,0\% berusia berkisar 21-30 tahun dengan presentase $58,1 \%$ dimaan itu merupakan usia produkrif dengan masa kerja rata-rata selama 2-5 tahun dengan presentase $48,4 \%$.

Tabel 2 Uji Validitas dan Reliabilitas

\begin{tabular}{|c|c|c|c|c|c|c|c|c|}
\hline \multirow{2}{*}{$\begin{array}{l}\text { Lingkungan } \\
\text { Kerja Fisik }\end{array}$} & \multirow{2}{*}{$\begin{array}{l}\text { Pearson } \\
\text { Correlation }\end{array}$} & \multicolumn{2}{|c|}{ Lingkungan } & \multirow{2}{*}{$\begin{array}{l}\text { Pearson } \\
\text { Correlation }\end{array}$} & \multirow{2}{*}{$\begin{array}{l}\text { Stres } \\
\text { Kerja }\end{array}$} & \multirow{2}{*}{$\begin{array}{l}\text { Pearson } \\
\text { Correlation }\end{array}$} & \multirow{2}{*}{$\begin{array}{l}\text { Kinerja } \\
\text { Karyawan }\end{array}$} & \multirow{2}{*}{$\begin{array}{l}\text { Pearson } \\
\text { Correlation }\end{array}$} \\
\hline & & $\begin{array}{l}\text { Kerja } \\
\text { Fisik }\end{array}$ & Non & & & & & \\
\hline LF1 & 0,835 & LNF1 & & 0,439 & SK1 & 0,723 & KK1 & 0,530 \\
\hline LF2 & 0,637 & LNF2 & & 0,379 & SK2 & 0,828 & KK2 & 0,560 \\
\hline LF3 & 0,684 & LNF3 & & 0,621 & SK3 & 0,840 & KK3 & 0,443 \\
\hline LF4 & 0,695 & LNF4 & & 0,497 & SK4 & 0,871 & KK4 & 0,344 \\
\hline LF5 & 0,812 & LNF5 & & 0,560 & SK5 & 0,815 & KK5 & 0,619 \\
\hline LF6 & 0,764 & LNF6 & & 0,480 & SK6 & 0,833 & KK6 & 0,377 \\
\hline LF7 & 0,708 & LNF7 & & 0,480 & & & & \\
\hline & & LNF8 & & 0,508 & & & & \\
\hline & & LNF9 & & 0,486 & & & & \\
\hline \multicolumn{9}{|c|}{ Cronbach's Alpha } \\
\hline \multicolumn{2}{|c|}{0,846} & \multicolumn{3}{|c|}{0,925} & \multicolumn{2}{|c|}{0,898} & \multicolumn{2}{|c|}{0,886} \\
\hline
\end{tabular}

Hasil dari uji validitas dapat diketahi dari tabel 2 menunjukan bahwa pernyataan pada masingmasing indikor dari variabel bebas dengan nilai Pearson Correlation melebihi nilai dari $\mathrm{r}_{\text {tabel }}$, sehingga butir pernyataan tersebut dikatakan valid.

Tabel 3 Uji Asumsi Klasik

\begin{tabular}{|c|c|c|c|c|c|c|}
\hline \multirow[t]{2}{*}{ Mdl } & \multicolumn{2}{|c|}{ Variabel } & \multirow{2}{*}{$\begin{array}{l}\text { Normalitas } \\
\text { Sig. }\end{array}$} & \multicolumn{2}{|c|}{ Multikolonieritas } & \multirow{2}{*}{$\begin{array}{c}\text { Heterokedastisitas } \\
\text { Sig. }\end{array}$} \\
\hline & Bebas & Terikat & & Tol. & VIF & \\
\hline \multirow[t]{3}{*}{1} & $\mathrm{LF}$ & \multirow{3}{*}{ KK } & \multirow{3}{*}{0,954} & 0,699 & 1,430 & 0,540 \\
\hline & LNF & & & 0,737 & 1,357 & 0,786 \\
\hline & SK & & & 0,582 & 1,718 & 0,847 \\
\hline
\end{tabular}

Berdasarkan tabel diatas dapat diketahui bahwa data tersebut berdistribusi secara normal dengan hasil sig. 0,954>0,1, serta tidak mengalami multikolonieritas dengan nilai tolerance $>0,05$ dan nilai VIF > 10 dan tidak mengalami heterokedastisitas. 
Tabel 4 Pengujian Hipotesis

\begin{tabular}{ccccccc}
\hline Mdl & \multicolumn{2}{c}{ Variabel } & \multicolumn{2}{c}{ Stand. Coeff. } & \multicolumn{2}{c}{ Keof. Detr. } \\
& Bebas & Terikat & Beta & $\mathrm{t}$ & Sig. & Adj. R Sq \\
\hline 1 & LF & \multirow{2}{*}{ KK } & $-0,163$ & $-1,638$ & 0,113 & \\
& LNF & & 0,782 & 8,051 & 0,000 & 0,791 \\
& SK & & 0,286 & 2,613 & 0,015 & \\
\hline
\end{tabular}

Berdasarkan pada tabel 4 dapat diketahui bahwa hasil pengujian hipotesis menunjukan bahwa H1 tidak diterima dengan nilai sig. $0,113 / 2=0,0565>0,05$. $\mathrm{H} 2$ diterima dengan nilai sig. $0,000 / 2=0$ $<0,05$. H3 diterima dengan nilai sig. $0,015 / 2=0,0075<0,05$. Pengaruh lingkungan kerja fisik, non fisik dan stres kerja terhadap kinerja karyawan memiliki Adjusted R Square sebesar 79,1\% dan 20,9\% dipengaruhi oleh faktor lain.

\section{HASIL DAN PEMBAHASAN}

Berdasarkan analisis penelitian data yang dilakukan pada Pabrik Suka Rasa Bakery dengan jumlah responden sebanyak 31 orang karyawan, maka dapat diketahui bahwa Pabrik Suka Rasa Bakery didominasi oleh karyawan perempuan dengan rata-rata usia 21-30 tahun yang berarti dalam kategori usia produktif dengan masa kerja rata-rata 2-5 tahun. Dari hasil perhitungan masing-masing indikator pada lingkungan kerja fisik, yaitu pewarnaan ruangan menjadi pilihan terbanyak dengan 25 orang responden dan memilih sangat setuju. Untuk masing-masing item indikator lingkungan kerja non fisik, karyawan tidak menyalagunakan fasilitas perusahaan, menjadi pilihan terbanyak dengan 20 orang responden memilih setuju. Untuk masing-masing item indikator stres kerja, karyawan ditempatkan sesuai kemampuan yang dimiliki, menjadi pilihan terbanyak dengan 17 responden memilih setuju. Untuk masing-masing item indikator kinerja karyawan, karyawan mampu menyelesaikan pekerjaan sesuai target yang ditentutkan perusahaan, sebanyak 17 responden memilih setuju dan karyawan mengerjakan pekerjaan secara bersama-sama, sebanyak 17 responden memilih setuju.

Dari hasil pengujian data, didapatkan hasil regresi dengan nilai koefisien $\beta$ pada konstanta $=$ 1,266 , lingkungan kerja fisik memiliki nilai $\beta=-230$, lingkungan kerja non fisik memiliki nilai $\beta=$ 0,640 dan untuk stres kerja memliki nilai $\beta=0,309$ dengan persamaan regresi sebagai berikut $\mathrm{Y}=$ $1.266+-0,230 \mathrm{X}_{1}+0,640 \mathrm{X}_{2}+0,309 \mathrm{X}_{3}+\mathrm{e}$. Kemudian untuk hasil analisis uji $\mathrm{f}$ pada tabel ANOVA, diperoleh nilai $\mathrm{f}_{\text {hitung }}=38,903$ dan nilai signifikansi sebesar 0,000. Maka dapat disimpulkan bahwa nilai signifikansi $0,000<0,05$ yang artinya variabel independen dalam penelitian ini yaitu variabel lingkungan kerja fisik (LF), variabel lingkungan kerja non fisik (LNF) dan variabel stres kerja (SK) secara bersama-sama atau simultan berpengaruh terhadap variabel dependen yaitu kinerja karyawan $(\mathrm{KK})$. Berdasarkan hasil olah data dalam analisis regresi diperoleh nilai koefisien determinan $\left(\mathrm{R}^{2}\right)$ antara variabel lingkungan kerja fisik (LF), lingkungan kerja non fisik (LNF), stres kerja (SK) dan kinerja karyawan (KK) sebesar 0,791 maka dapat dikatakan bahwa besarnya pengaruh ketiga variabel indepeden terhadap variabel dependen sebesar 79,1\% dan terdapat pengaruh dari faktor lain sebesar $20,9 \%$.

Berdasarkan penelitian yang telah dilakukan, didapatkan hasil bahwa lingkungan kerja fisik tidak berpengaruh signifikan terhadap kinerja karyawan Pabrik Suka Rasa Bakery. Hasil ini berdasarkan analisis regresi yang telah dilakukan dengan uji thitung sebesar -1,638 dengan sig. 0,113/2 $=0,0565$ dengan menggunakan taraf signifikan 5\% maka diperoleh probabilitas yaitu $0,0565>0,05$ sehingga dapat disimpulkan bahwa lingkungan kerja fisik tidak berpengaruh signifikan terhadap kinerja karyawan Pabrik Suka Rasa Bakery. Hal ini bisa terjadi karena terdapat variabel lain yang lebih berpengaruh. Hasil penelitian ini serupa dengan hasil penelitian yang sebelumnya telah dilakukan oleh Widianingrum dan Djastuti (2016) yang menyatakan bahwa hasil dari penelitiannya yaitu variabel lingkungan kerja fisik tidak memiliki pengaruh yang signifikan terhadap variabel kinerja karyawan. 
Berdasarkan penelitian yang telah dilakukan, didapatkan hasil bahwa lingkungan kerja fisik berpengaruh positif dan signifikan terhadap kinerja karyawan Pabrik Suka Rasa Bakery. Hasil ini berdasarkan analisis regresi yang telah dilakukan dengan uji thitung sebesar 8,051 dengan sig. 0,000/2 $=0$ dengan menggunakan taraf signifikan 5\% maka diperoleh probabilitas yaitu $0<0,05$ sehingga dapat disimpulkan bahwa semakin baik lingkungan kerja non fisik maka akan menaikan kinerja karyawan pada Pabrik Suka Rasa Bakery dan sebaliknya. Hasil penelitian ini sesuai dengan hasil penelitian yang sebelumnya telah dilakukan oleh Eka dkk. 2016 menyatakan variabel lingkungan kerja non fisik mempunyai pengaruh positif dan signifikan terhadap variabel kinerja karyawan.

Berdasarkan penelitian yang telah dilakukan, didapatkan hasil bahwa stres kerja berpengaruh positif dan signifikan terhadap kinerja karyawan Pabrik Suka Rasa Bakery. Hasil ini berdasarkan analisis regresi yang telah dilakukan dengan uji $t_{\text {hitung }}$ sebesar 2,613 dengan sig. 0,015/2 =0,0075 dengan menggunakan taraf signifikan 5\% maka diperoleh probabilitas yaitu 0,0075<0,05 sehingga dapat disimpul bahwa semakin tinggi tekanan yang karyawan terima dengan catatan dilakukan pengelolaan yang tepat maka akan meningkatkan kinerja karyawan pada Pabrik Suka Rasa Bakery. Stres yang dialami karyawan tidak selalu berdampak negatif melainkan mampu berdampak positif karena mampu memberikan motivasi bagi karyawan untuk lebih semangat sehingga meningkatkan kinerja karyawan (Akbar et al., 2017:44). Hasil penelitian ini sesuai dengan hasil penelitian yang sebelumnya telah dilakukan oleh Tri Wartono (2017) menunjukan hasil penelitian yaitu terdapat pengaruh yang signifikan dan positif antara variabel stres kerja terhadap variabel kinerja.

Berdasarkan penelitian yang telah dilakukan, didapatkan hasil bahwa lingkungan kerja fisik, lingkungan kerja non fisik dan stres kerja secara simultan atau bersama-sama berpengaruh terhadap kinerja karyawan pada Pabrik Suka Rasa Bakery. Hasil ini berdasarkan pada uji f dan didapatkan nilai signifikansi $0,000<0,05$ yang artinya variabel independen dalam penelitian ini yaitu variabel lingkungan kerja fisik, variabel lingkungan kerja non fisik dan variabel stres kerja secara bersamasama atau simultan berpengaruh terhadap variabel dependen yaitu kinerja karyawan.

\section{PENUTUP}

Berdasarkan hasil penelitian yang telah dilakukan dapat disimpulkan bahwa lingkungan kerja non fisik dan stres kerja berpengaruh positif dan signifikan terhadap kinerja karyawan. Sehingga apabila lingkungan kerja non fisik tersedia dengan baik dan membuat karyawan nyaman maka kinerja karyawan akan naik dan apabila karyawan mengalami stres dan tekanan yang tinggi dengan pengelolaan yang tepat akan meningkatkan kinerja karyawan. dengan hasil penelitian ini maka diharapkan pihak perusahaan harus lebih memperhatikan faktor-faktor pada lingkungan kerja non fisik guna lebih meningkatkan lagi kinerja karyawan serta stres kerja yang dikeola dengan baik mampu berpengaruh positif terhadap kinerja karyawan sehingga harus dipertahankan dan ditingkatkan lagi pengelolaan stres kerja pada Pabrik Suka Rasa Bakery. Untuk penelitian selajutnya diharapkan menambahkan variabel lain untuk dapat meningkatkan variabel kinerja.

Pada pelaksanaan penelitian masih memiliki keterbatasan dikarenakan kuesioner tidak dibagikan langsung kepada responden melaikan melalui perantara HRD sehingga peneliti tidak dapat mengetahui apakah responden mengisi kuesioner sesuai prosedur dan peneliti hanya menggunakan metode kusioner tanpa melakuakan wawancara langsung sehingga hasil penelitian hanya berdasarkan data pada kuesioner.

\section{REFERENSI}

Ahmad, Ekayanti Hafidah dkk. 2018. "Relationship of Work Stress to the Performance of Intensive Care Unit Nurses in Makassar." American Journal of Public Health Research 6(1): 18-20.

Aji, Oleh A, dan Tri Budianto. 2015. "Pengaruh Lingkungan Kerja Terhadap Kinerja Pegawai Pada PT Perusahaan Gas Negara ( Persero ) Tbk Sbu Distribusi Wilayah I Jakarta.” Manajemen 3(1).

Akbar, Dinnul Alfian, Negeri Raden, dan Fatah Palembang. 2017. "Konflik Peran Ganda Karyawan Wanita Dan Stres Kerja." 12: 33-48.

Aslami, Nuri, dan Yeni Absah. 2018. "The Effect Of The Non-Physical Work Environment And Job 
Insecurity On The Performance Of Outsourcing Employee Business Support Through The Motivation As Intervening Variable At Pt . Telekomunikasi." Business And Management 46(Ebic 2017): 376-83.

Eka, Dwi Silvia. 2016. "Kepuasan Kerja Dan Kinerja Karyawan ( Studi Pada Karyawan PT Telkom Indonesia Witel Jatim Selatan Malang ).” Administrasi Bisnis 40(1): 76-85.

Hamid, Djamhur, M Djudi Mukzam, dan Ferdinan Fatikim. 2017. "Pengaruh Konflik Kerja Dan Stres Kerja Terhadap Kinerja Karyawan ( Studi Pada Karyawan PT . Bank Rakyat Indonesia ( Persero ) Cabang Soekarno Hatta Malang ).” Administrasi Bisnis 47(1): 172-80.

Iqbal, Muhammad. 2016. "Pengaruh Konflik Peran Ganda Dan Stres Kerja Terhadap Kinerja Pegawai Wanita Pada Rumah Sakit Umum Daerah Menggala." Universitas Lampung.

Joseph, Intan. 2016. "Analysis The Influence Of Physical Work Environment And Non-Physical Work Environment On Employee Productivity In General Hospital Gmim Kalooran Amurang South Minahasa Regency." 16(4): 407-20.

Noorainy, Fitria. 2017. "Pengaruh Lingkungan Kerja Fisik Dan Non Fisik Terhadap Kinerja Pegawai Pada Sekretariat Daerah Kabupaten Pangandaran.” 1(2).

Oemar, Usailan, dan Leo Gangga. 2017. "Pengaruh Stres Kerja Terhadap Kinerja Pegawai Pada Dinas Pendapatan, Keuangan Dan Aset Daerah Kabupaten Musi Manyuasin.” ecoment global 2.

Rosita, Riska, dan Nadila Wahyu Cahyani. 2019. "Hubungan Antara Stres Kerja Dengan Kinerja Petugas Rekam Medis."

Virgiyanti, dan Bambang Swasto Sunuharyo. 2018. "Pengaruh Lingkungan Kerja Fisik Dan Non Fisik Terhadap Kinerja Karyawan (Studi Pada Karyawan Divisi Fresh PT. Trans Retail Indonesia (Carrefour) Plaza Tangerang City).” Administrasi Bisnis 61.

Wartono, Tri. 2017. "Pengaruh Stres Kerja Terhadap Kinerja Karyawan (Studi Pada Karyawan Majalah Mother And Baby)." ilmiah prodi Manajemen.

Widianingrum, Ayu, dan Indi Djastuti. 2016. "Pengaruh Lingkungan Kerja Fisik,Lingkungan Kerja Nonfisik Dan Stres Kerja Terhadap Kinerja Karyawan( Studi Pada PT . Kereta Api Indonesia ( PERSERO ) Daerah Operasional IV Semarang ).” 5: 1-10. 